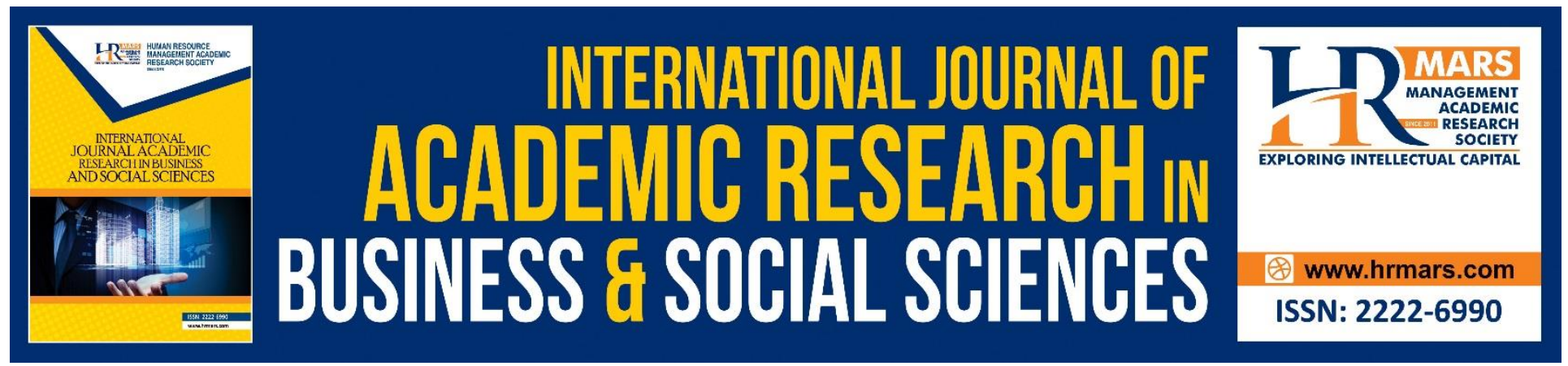

\title{
ErIn: Fun Learning with Instagram Using Instagram Poll to Learn Tenses
}

Samihah binti Ab Razak, Elmy Ezayane binti Md Emary, Wan Nor Eili Syairah binti Wan Ibrahim \& Melor Md Yunus

To Link this Article: http://dx.doi.org/10.6007/IJARBSS/v9-i1/5461

DOI: $10.6007 /$ IJARBSS/v9-i1/5461

Received: 08 Jan 2019, Revised: 24 Jan 2019, Accepted: 09 Feb 2019

Published Online: 14 Feb 2019

In-Text Citation: (Razak, Emary, Ibrahim, \& Yunus, 2019)

To Cite this Article: Razak, S. binti A., Emary, E. E. binti M., Ibrahim, W. N. E. S. binti W., \& Yunus, M. M. (2019). ErIn: Fun Learning with Instagram Using Instagram Poll to Learn Tenses. International Journal of Academic Research in Business and Social Sciences, 9(1), 597-608.

\section{Copyright: (C) 2019 The Author(s)}

Published by Human Resource Management Academic Research Society (www.hrmars.com)

This article is published under the Creative Commons Attribution (CC BY 4.0) license. Anyone may reproduce, distribute, translate and create derivative works of this article (for both commercial and non-commercial purposes), subject to full attribution to the original publication and authors. The full terms of this license may be seen

at: http://creativecommons.org/licences/by/4.0/legalcode

\section{Vol. 9, No. 1, 2019, Pg. 597 - 608}

Full Terms \& Conditions of access and use can be found at http://hrmars.com/index.php/pages/detail/publication-ethics 


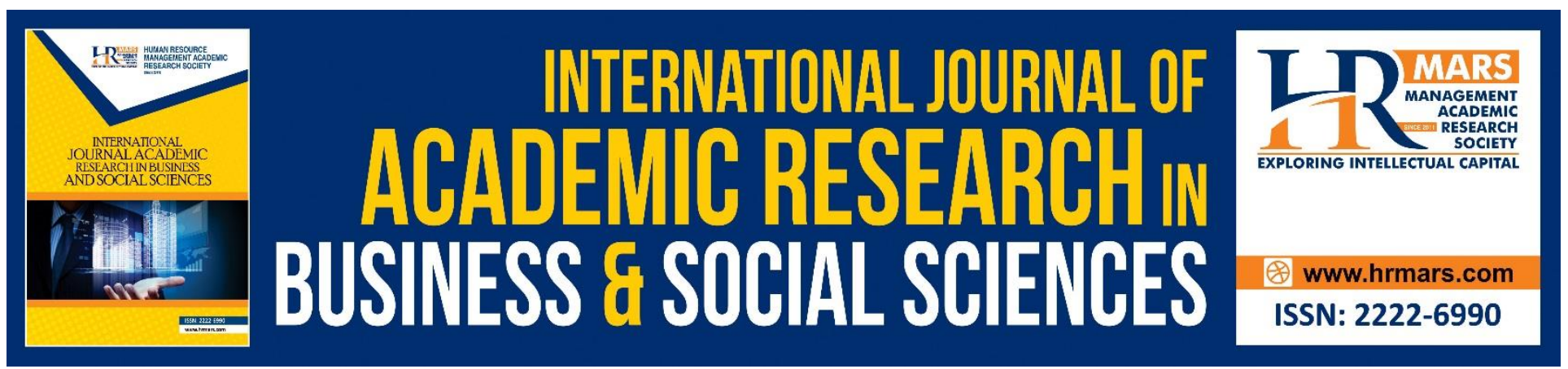

\title{
Erln: Fun Learning with Instagram Using Instagram Poll to Learn Tenses
}

\author{
Samihah binti Ab Razak ${ }^{3}$, Elmy Ezayane binti Md Emary ${ }^{23}$, Wan \\ Nor Eili Syairah binti Wan Ibrahim ${ }^{3} \&$ Melor Md Yunus ${ }^{3}$ \\ Sekolah Menengah Kebangsaan Seri Aman, 16800 Pasir Puteh, Kelantan, Malaysia ${ }^{1}$ \\ Sekolah Menengah Kebangsaan Raja Abdullah, 52000 Kuala Lumpur, Malaysia² \\ Universiti Kebangsaan Malaysia, 43600 Bangi, Selangor, Malaysia ${ }^{3}$
}

\begin{abstract}
Nowadays, social media is widely used and popular among school students. It is believed that incorporating Social Media Assisted Language Learning (SMALL) in the teaching and learning process can help the students to learn English better. ErIn, a program based on SMALL was created to help the students learn the correct use of tenses in an interactive and fun way by using the feature poll on Instagram. This study aimed to enhance the secondary school students' performance in using the tenses correctly by participating in ErIn. The study also examined the students' perception of ErIn. 30 Form 1 students from 2 schools each in Pasir Puteh, Kelantan and Kuala Lumpur were involved in this study where they were identified having problem in tenses area. The research design was action research using Kemmis and McTaggart's model. The data were collected through the pre-test, posttest and questionnaire. The finding showed that the students' performance was increased significantly after they participated in the program. Besides, the result from the students' perception questionnaire revealed that they had positive attitudes towards the program as they perceived it was very helpful in helping them learn the tenses. Therefore, these findings may be used to help the other English teachers to incorporate SMALL in helping their students in tenses area.
\end{abstract}

Keywords: Instagram, poll, Social Media Assisted Language Learning (SMALL), students' perception, tenses

\section{Introduction}

The conventional teaching method which is 'chalk-and-talk' now seems to be the thing of the past. Along with the technological developments, the education system has also begun to incorporate the use of technology into the teaching and learning process. It is to ensure that the teaching and learning process is more interactive than it has ever been before. This is supported by the research conducted by Fadila, Mahamod, and Mohamad (2016) who found out that the technology provided a variety of forms and choices where it facilitated teachers' works and prevented students from 
getting bored. From the use of simple projectors as teaching tools to the use of educational applications such as Kahoot, Quizziz, Google Classroom, Quizlet and Padlet, teachers are continuously trying to find new ways to keep the lesson exciting and interesting. According to Perselli (2014), schools had continuously made an investment in digital technologies such as desktop computers, laptops and tablets. One of the technologies which are also popular in language learning is mobile devices. As mentioned by Hashim, Yunus and Embi (2018), mobile devices provided learning materials which were movable, flexible and independently controlled which can make the students extend the learning environment.

Recently, social media has become the subject of interest among educators because teenagers and social media nowadays are practically inseparable. They have their phones glued to their hands around the clock and most of that time is spent on social media such as Instagram, Facebook, Twitter, Snapchat, YouTube and Smule. Based on Global Digital Report 2018 by Hootsuit and We Are Social, $75 \%$ of Malaysians spent roughly 3 hours daily using social media and this had put Malaysia at 9th place in the world ranking. From this statistics, it can be deduced that the teenagers are familiar with social media like Facebook, Instagram and Twitter (Dimassi \& Theologou, 2018). In fact, according to Marsh (2016), the children were believed to be engrossed in a digital landscape from birth. Hence, it is undeniably helpful and relevant to integrate technology like social media in English language teaching and learning process. It is because school children are confident and competent to use it in their daily basis. In addition, the stress on 4Cs - critical thinking, communication, collaboration and creativity from the implementation of 21-st century learning has also encouraged the teachers to be creative and innovative in their class in order to attend to these Gen Z's needs. Thus, the focus will be put more on the students' interaction and their enjoyment on the lesson over grades rather than the teachers (Jackson, 2017). Social Media Assisted Language Learning (SMALL) is one of the ways to enhance English language teaching and learning process as social media is a part of students' lives (Chuah 2013). Instagram is one of the most active and popular social media platforms among teenagers. According to Moshi et. al (2018), integrating social media in the lesson would offer an exciting learning environment that assisted the students to improve their English.

The focus of this study was limited to the use of Erln, one of the many programs that derived from SMALL. ErIn is a short form from the phrase Error Identification. It provides students with an interactive and fun way to learn English not only in the class (offline) but also at home (online). This is supported by research done by Gleason and von Gillern (2018) that stated social media can be used as a way to develop learning networks that connected students' offline and online activities. In this study, the students were identified having problems in using the tenses especially during the error identification activities. Thus, this paper aimed to find out the effectiveness of using Erln in teaching the correct uses of tenses to the students and their perception of ErIn. 


\section{Literature Review}

The Rise of Social Media

Social media can be defined as websites and applications that allow people to create online communities to share information and content like photos, opinion and events quickly, efficiently and in real-time. Thus, it has become an essential part of many people's lives today. Social media has undergone many changes in a span of 30 years. It started with the invention of the World Wide Web in 1989 by Tim Berners-Lee where it provided a platform for social networking. Then, in 1997, the first social media site, called Six Degrees was created. It allowed people to create profiles, add friends and share opinions in forums; the things that people usually do with their social media nowadays. 2002 and 2003 can be described as 'social media surge' where social media started to gain its popularity with the launch of Friendster in 2002 that used elements in Six Degrees and LinkedIn in 2003 that offered networking resources for businesses and professionals. Starting from those years, social media has become prevalent with many sites popping out on the internet like MySpace (2003), Facebook (2004), YouTube (2005), Twitter (2006), Instagram (2010) and Snapchat (2011). Besides, the popularity of social media nowadays is also supported by its accessibility since it can not only be assessed via computer and laptop but also mobile phone.

Social media is mainly used to connect with people across the globe. With the existence of social media, the distance is no longer a barrier for people from different countries or even different continents to get connected with each other. Even being separated by thousands of kilometers, people can still keep up with the daily happenings of their friends and family via social media like Facebook, Twitter and Instagram. Social media does not only connect people but it is also a way of keeping people updated with the news and current issues that happen in the country and around the world. News updates can be accessed more quickly and easily on daily basis. In other words, the emergence of social media has helped the people to obtain all the information needed at their fingertips. Moreover, businessmen now have a larger market for the reason that they now can reach out to people everywhere and no longer need to travel. Using social media as the marketing strategy to promote products can not only save time and energy but also cut the cost as it is free of charge. Thus, it is understandable why many people choose to do online business using their social media nowadays as it is more convenient, cost-free and usually see measurable results. In Malaysia, 58,824 online businesses have registered with the Companies Commission of Malaysia as of February 2018 and this is proof to show how popular social media is as a platform for online business. Today, the social media world cannot be separated from people's everyday lives and it definitely does not show any signs to stop growing from year to year.

Malaysian Youth and Social Media

Ranking among the largest social media users in the Asia Pacific region; according to Go-globe 2015, Malaysia has experienced an increased percentage of internet penetration. Go-globe declared that social media penetration in Malaysia was the 6th highest in the Asia Pacific region at the percentage of $53 \%$ and an average of 3.3 hours was spent by Malaysians on social media daily. It placed Malaysia at number 3 of the highest social media users in the region after the Philippines and Thailand. Based on the survey conducted by the Malaysian Communications and Multimedia 
Commission (MCMC), in early 2015, the rate of internet penetration in Malaysia was $70.4 \%$. The percentage has increased to $76.9 \%$ in 2016 and $85.7 \%$ in 2017. These increases are the indicator to show that the internet is widely used by Malaysians and has become a part of their lives. One of the factors contributes to these increases is the use of social media like Facebook and Twitter among Malaysians.

Social media is primarily used as a mean to connect with peers in real time even being separated by a large physical distance. Nowadays, we can see teenagers everywhere using social media such as Instagram and Twitter as a platform to connect with their friends by sharing updates, pictures, opinions, comments and views. A study conducted by Yusop and Sumari (2013) found that most students spent $88 \%$ of their time online; socializing on a variety of social media sites every day. In Malaysia, it is no doubt that youth are the avid users of social media. This statement is supported with a study by Ahmad, Ismail and Nasir (2015) where it was revealed that the largest numbers of social media users in Malaysia are those aged 13 to 34 . These people are on social media at an extended period of time for the different purposes which include socialization, communication, building and maintaining the relationship, overcoming loneliness, sharing information and learning.

In addition, by using social media, the youth can not only connect with their peers but also share their same interest such as music and film. Baboo, Pandian, Prasad and Rao (2013) pointed out that Malaysian youth mostly used social media for entertainment such as downloading music and video files and playing online games to fill their spare time and release stress. Besides, Malaysian youth also use social media to search for information and for educational purposes (Yin, Agotinho, Harper and Chicharo 2014). Some students can use social media as a platform to exchange examination questions with other students from other states and do virtual study groups with their peers. Thus, the students are able to spend their time on social media with beneficial activities. This can definitely stop the public's negative perception that social media is only for socializing and entertainment.

\section{Social Media in Education}

The use of social media for the purpose of language learning is not a new occurrence and research has been conducted regarding this. According to Mokhtar and Dzakiria (2015), when the social network is blended with education, it is the highest peak of e-learning utilization. It is observed that students tend to use a lot of English when they are sharing information or views on social media. Even if they have grammatical mistakes, this is still considered a great way for them to keep practicing their English. Some students who actively use social media have shown some improvements in their second language particularly in terms of vocabulary and sentence structures. This proves that new information that is gained in an informal and enjoyable setting is more easily retained, even if it is unintentionally. This leads to the ideas of using social media as one of the effective learning tools which can help students learn a topic better. According to the research by Idris and Ghani (2012), the use of social media like Facebook could help to improve the students' English proficiency as it is able to promote the students' reflective thinking and knowledge construction. This is based on the hopes of teachers that the students will continue the learning process even when they are not in a formal 
learning environment. Since they spend most of their time on social media, it is believed that it is possible to make them learn something while they are interacting in social media with their friends. They do not have to be constricted to a rigid learning time schedule as they are able to learn English at any time they prefer. With the emergence of social media like Instagram and Facebook, Social Media Assisted Language Learning (SMALL) has become a new phenomenon that educators have taken interest in to help the students learn the target language better.

When learning a new language like English, one of the most frequently asked questions is of those that involved tenses. No matter how hard teachers go through tenses rules in class, students still find it hard to memorize all those rules. Therefore, the search for the most effective method to teach grammar is ongoing so that the students can learn grammar and memorize the rules better. It is believed that an interactive way of teaching is effective to help the students memorize better. This is where SMALL comes in. Al-Rahmi and Othman (2016) in their study revealed that using social media in teaching and learning process can give positive impact to the students' academic performance. Thus, integrating social media to teach tenses can provide the students with an environment where they can learn tenses in a fun, enjoyable and interactive way. The students can have a better understanding of the tenses rules as well as be more motivated to participate in the lesson. It is because they are familiar and comfortable with the platform used, which is social media. Furthermore, Mokhtar and Dzakiria (2015) posited that the respondents in their study found that the lesson became easier and more engaging because they were interacting and conversing with peers online. In other words, the ideal situation for effective grammar learning is when the students are relaxed, having fun and interacting with their peers. Therefore, it is believed that integrating SMALL to teach tenses can increase the students' performance in learning the target language.

\section{Methodology}

The research design chosen was the action research using Kemmis and McTaggart's model. The study was carried out at 2 secondary schools each in Pasir Puteh, Kelantan and Kuala Lumpur. This action research was chosen to see the effectiveness of using Erln, a program derived from SMALL in learning the tenses rules and also the students' perception of using ErIn. For this purpose, 30 form 1 students participated in the program. Most of them were average and weak students where they were identified having trouble in tenses area, especially during the error identification activities. 


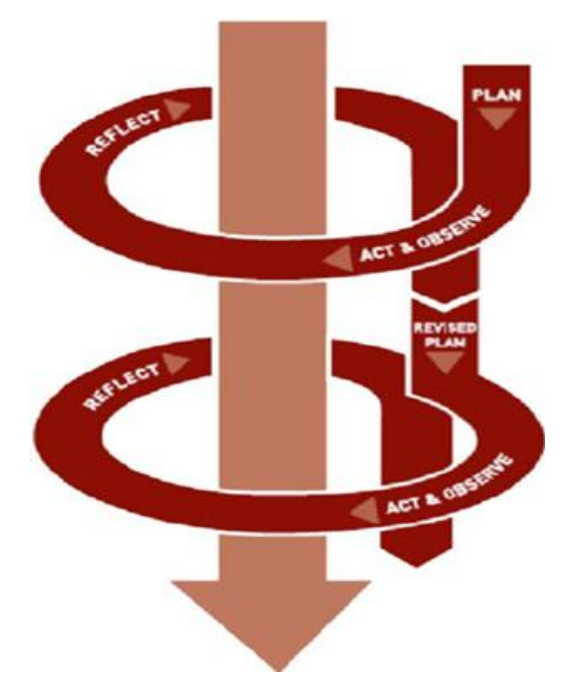

Figure 1: Kemmis and McTaggart's Model

The instruments used to collect the data were the students' pre-test and post-test result and the questionnaire, using a 5-point Likert scale. The students sat for the pre-test where they had to answer 3 sets of error identification activity containing 25 questions that tested them on the various tenses. After the pre-test, the students were asked to follow the teacher's Instagram account in order for them to participate in the ErIn program.

During the execution of Erln, the students were exposed to various exercises of tenses in series of the polls posted by the teacher on the Instagram account. This program was conducted for 3 weeks in order to familiarize the students with the tenses rules. The students were encouraged to be actively engaged in the program by choosing and voting for the correct answers. After the polls were closed, the results were discussed using the comment section where teacher and students could interact with one another. The teacher could choose to give constructive feedback to the students either individually (direct message) or in a group (comment section).

After that, the students sat for the post-test using the same questions as in pre-test to see the effectiveness of ErIn in improving the students' English, especially in tenses area. At the end of the program, the 10-item questionnaire using 5-point Likert scale was distributed to the students to identify the students' perception of ErIn. The data collected for the pre-test and post-test and the questionnaire were computed and analyzed and the results were then reported.

\section{Findings and Discussion}

The findings were divided into 2 sections. First, the results for the effectiveness of Erln were presented and discussed. Then, it was followed by the results for the students' perception of ErIn. Analyses of these two had yielded valuable information about how SMALL can be used to help the students to learn English better. 
The Effectiveness of Erln

Based on Table 1 below, there were 53\% of students who scored below 10 during the pretest. It was 16 out of 30 students who took part in the program and these results were quite alarming. $44 \%$ of students managed to score the marks ranging from $11-15$ and only $3 \%$ of students, which was equal to one student was in the $16-20$ mark range. Besides, none of the students was able to get into $21-25$ mark range. It can be concluded that almost all of the students who participated in the ErIn program were considered weak and average students and they had difficulty in using the tenses correctly.

After participating in the ErIn program for 3 weeks and then sitting for the post-test, the results showed substantial rises in the students' performances. In the post-test, $37 \%$ of students were successful to get into $21-25$ mark range compared to the pre-test where none of them managed to do so. There were $53 \%$ of students in $16-20$ mark range and only $10 \%$ of students were in $11-15$ mark range. These rises indicated that the ErIn program succeeded in helping the students to learn the correct uses of tenses.

\begin{tabular}{ccc}
\hline Mark Range & $\begin{array}{c}\text { Pre-Test } \\
(\%)\end{array}$ & $\begin{array}{c}\text { Post-Test } \\
(\%)\end{array}$ \\
\hline $0-5$ & 3 & 0 \\
$6-10$ & 50 & 0 \\
$11-15$ & 44 & 10 \\
$16-20$ & 3 & 53 \\
$21-25$ & 0 & 37 \\
\hline
\end{tabular}

Table 1: Mark Comparison Between Pre-Test and Post-

Test

The results indicated that the integration of SMALL-based program could actually help the students to learn the tenses rules. This is because the students are able to perform and learn better when they are comfortable with the medium used during the teaching and learning process and in this case, is Instagram. This is concurred with the research by Moshi et. al (2018) where it was found that integrating social media in the lesson would offer an exciting learning environment that assisted the students to improve their English. Besides, integrating SMALL for teaching and learning process can motivate and encourage the students to be actively engaged in the lesson, especially those who are quiet and shy. According to Mokhtar and Dzakiria (2015), the lesson became easier and engaging when the students were interacting and conversing with peers online. It is because some students are not comfortable to speak in the classroom because they do not want to be the centre of the attention. Therefore, SMALL-based program can help these kinds of students and they will not be left behind.

\section{Students' Perception of Erln}

The first item in the questionnaire was intended to find out the number of students who had any experiences in participating in a SMALL program before. Based on Table 2 below, only $43 \%$ of 
students had taken part in the SMALL program before while $57 \%$ of them did not have any experience in doing so.

Meanwhile, the items from number 2 to 10 in the questionnaire aimed to discover the students' perception of ErIn. The mean of percentages for item 2 to 10 was calculated. It was inferred that more than $98 \%$ of students had positive views on the use of ErIn. They agreed that ErIn played a significant role in helping them to learn the tenses rules better. All of the students were in consensus that they could learn the tenses easily using Erln as it was more fun. In addition, they also had more time to work on the answers as each poll was opened for 24 hours. From the questionnaire, the students had positive views on the use of ErIn because they were able to get fast response and feedback from the teacher. They were also able to interact actively with their teacher and friends during the discussion in the comment section or they could message their teacher personally by using a direct message. Besides, the exciting learning environment provided by ErIn in teaching the tenses rules also helped the students to do better in the post-test. It was because the students were comfortable and more motivated to learn the tenses using a medium that they were familiar with and in this case was Instagram.

\begin{tabular}{|c|c|c|c|c|}
\hline No. & Item & $\begin{array}{l}\text { Disagre } \\
\text { e } \\
(\%)\end{array}$ & $\begin{array}{l}\text { Neutral } \\
(\%)\end{array}$ & $\begin{array}{l}\text { Agree } \\
(\%)\end{array}$ \\
\hline 1. & I have participated in this kind of program before. & 57 & & 43 \\
\hline 2. & I feel that it is easier for me to learn grammar this way. & & & 100 \\
\hline 3. & I feel that it is more fun to learn grammar this way. & & & 100 \\
\hline 4. & $\begin{array}{l}\text { I feel the time flexibility helps a lot in enabling me to } \\
\text { participate in this program. }\end{array}$ & & & 100 \\
\hline 5. & $\begin{array}{l}\text { Learning grammar this way helps me to memorize the } \\
\text { rules better. }\end{array}$ & & 7 & 93 \\
\hline 6. & $\begin{array}{l}\text { The explanation that the teacher provides after each } \\
\text { exercise helps a lot. }\end{array}$ & & & 100 \\
\hline 7. & $\begin{array}{l}\text { Fast response and feedback from the teacher after each } \\
\text { exercise helps a lot. }\end{array}$ & & 7 & 93 \\
\hline 8. & $\begin{array}{l}\text { This program helps me to memorize grammar rules } \\
\text { better in a shorter time. }\end{array}$ & & 3 & 97 \\
\hline 9. & I prefer doing grammar exercise this way because I can & & & 100 \\
\hline 10. & $\begin{array}{l}\text { interact with fellow students and the teacher better. } \\
\text { I feel that my ability to answer tenses question has } \\
\text { improved a lot thanks to this program }\end{array}$ & & & 100 \\
\hline
\end{tabular}

Table 2: Students' Perception of Erln

The findings showed that the use of ErIn in learning process played a significant role in helping the students to improve their use of tenses. ErIn helps the students to learn English not only in the 
class but also at home. In other words, the learning process will not be stopped at the end of the lesson but it will be continued even after the school hour. So, the students are able to spend their time on social media with beneficial activity. This is in line with the research done by Gleason and von Gillern (2018) that found social media provided learning networks that connected students' offline and online activities. Moreover, Erln also acts as a helper to the teacher as sometimes the teacher is not able to attend to all the students' needs during the teaching and learning process because of the time constraint. The teacher can spend more time with the students even after the school hour. By attending to all the students' needs using Erln, the teacher can ensure that the students would not be left behind and thus, the students' English can be improved.

\section{Conclusion}

Overall, a SMALL-based program does play an important role to help the students learn the tenses rules. All of 30 students who participated in the Erln program for 3 weeks had shown substantial rises in their post-test. This finding was in line with the study by Al-Rahmi and Othman (2016) that revealed using social media in teaching and learning process can give positive impact to the students' academic performance. Besides, the students also had positive perceptions of ErIn. Majority of them agreed they learnt tenses better using Erln since it was fun, flexible and they were able to interact actively with friends and teachers, as well as getting fast feedback. Based on the findings, it is recommended for the teachers to integrate SMALL-based program in their teaching and learning process as the lesson can be more interactive and effective. The language will be grasped by the students faster as they are learning it in an enjoyable and comfortable setting. In conclusion, it is hoped that this study could shed some light in the efforts of helping the students to improve their English and encourage the teachers to integrate SMALL-based program in their teaching and learning process.

\section{Acknowledgements}

We are very thankful to all the people from Faculty of Education, Universiti Kebangsaan Malaysia for supporting us to complete this research. Besides, we would like to convey our deepest appreciation towards the principals, teachers and students from Sekolah Menengah Kebangsaan Seri Aman, Pasir Puteh, Kelantan and Sekolah Menengah Kebangsaan Raja Abdullah, Kuala Lumpur for their willingness to take part in this research. We are really grateful with their warmth support and this study would not be possibly completed without their participation. Last but not least, we wish to express our gratitude to our parents and family members for their understanding, encouragement and endless support.

\section{Corresponding Authors}

Melor binti Md Yunus

Faculty of Education, Universiti Kebangsaan Malaysia, 43600 Bangi, Selangor, Malaysia 
INTERNATIONAL JOURNAL OF ACADEMIC RESEARCH IN BUSINESS AND SOCIAL SCIENCES

Vol. 9, No. 1, Jan, 2019, E-ISSN: 2222-6990 (C) 2019 HRMARS

\section{References}

Al-Rahmi, W.M. \& Othman, M.S. (2016). The Impact of Social Media Use on Academic Performance Among University Students: A Pilot Study. Journal of Information Systems Research and Innovation, $1-10$.

Baboo, S.B., Prasad, N.V., Pandian, A. \& Rao, A. (April 2013). Young People and New Media in Malaysia: An Analysis of Social Uses and Practices. International Refereed Research Journal, 4(2), 50 $-56$.

Dimassi, M., \& Theologou, S. (2018). Multiliteracy Approaches to Foreign Language Teaching : The Use of Web Tools. Multilingual Academic Journal of Education and Social Sciences, 6(1), 126-147. https://doi.org/10.6007/MAJESS/v6-i1/450

Fadila, N., Mahamod, Z. \& Mohamad, W.M.R. (2016). Competencies, Attitude and Application of Web 2.0 as a Teaching Aids among Malay Language Primary School Teachers. Malay Language Education Journal, 6(2), $52-58$.

Gleason, B. \& von Gillern, S. (2018). Digital Citizenship with Social Media: Participatory Practices of Teaching and Learning in Secondary Education. Educational Technology \& Society, 21(1), 200 $-212$.

GO-Globe (2015). Social Media Usage in Asia Pacific - Statistics and Trends. Retrieved November 8, 2018, from http://www.go-globe.com/blog/social-media-asia/

Hashim, H.,Yunus, M.M. \& Embi, M.A. (2018). Learning Through Mobile: Exploring the Views of Polytechnic ESL Learners. Journal of Teaching and Learning English in Multicultural Contexts, 2(1), $56-62$.

Ahmad, J., Ismail, N. \& Nasir, N.N.A. (2015). Investigating Malaysian Youth's Social Media Usage, Competencies and Practice with Regard to Crime Prevention: An Application of the Social Media Literacy Model. Second International Conference on Media, Communication and Culture.

Idris, H. \& Ghani, R.A. (2012). Construction of Knowledge on Facebook. Language, Linguistics and Literature, the Southeast Asian Journal of English Language Studies, 18(3), 61 - 72.

Jackson, S. (2017). 3 New Teaching Methods Improve the Educational Process. Retrieved September 10, 2018, from http://www.gettingsmart.com/2012/09/3-new-teaching-methods-improveeducational-process/ 
INTERNATIONAL JOURNAL OF ACADEMIC RESEARCH IN BUSINESS AND SOCIAL SCIENCES

Vol. 9, No. 1, Jan, 2019, E-ISSN: 2222-6990 (C) 2019 HRMARS

Malaysian Communications and Multimedia Commission (2015). Communications \& Multimedia Pocket Book of Statistics Q1 2015 [PDF]. Cyberjaya: Malaysian Communications and Multimedia Commission.

Malaysian Communications and Multimedia Commission (2016). Communications \& Multimedia Pocket Book of Statistics 2016 [PDF]. Cyberjaya: Malaysian Communications and Multimedia Commission.

Malaysian Communications and Multimedia Commission (2017). Communications \& Multimedia Pocket Book of Statistics 2017 [PDF]. Cyberjaya: Malaysian Communications and Multimedia Commission.

Marsh, J. (2016). The Digital Literacy Skills and Competencies of Children of Pre-School Age. Media Education: Studies and Research, 7(2), 178-195. doi:10.14605/MED721603

Mokhtar, F. A. \& Dzakiria, H. ( 2015). Illuminating the Potential of Edmodo as an Interactive Virtual Learning Platform for English Language Learning and Teaching. Malaysian Journal of Distance Education, 17(1), $83-98$.

Moshi, T.B., Ndeke, F.N., Stephen, A. \& Ngozi, E.O. (2018). Social Media Use Influence on Learning Behaviour of Secondary School Students in Moshi Municipality, Tanzania. The International Journal of Indian Psychology, 6(3), 83-92. dip:18.01.029/20180603 doi: 10.25215/0603.029

Yin, J.L.S., Agostinho, S., Harper, B., \& Chicharo, J.F. (2014). The Engagement of Social Media Technologies by Undergraduate Informatics Students for Academic Purpose in Malaysia. Journal of Information Communication and Ethics in Society, 12(3), 177 - 194.

Yusop, F.D. \& Sumari, M. (2013). The Use of Social Media Technologies among Malaysian Youth. Procedia - Social and Behavioral Sciences, 103(2013), 1204 - 1209.

Zulkifli. (2018). Statistik Pengguna Internet, Media Sosial, Mobile dan E-Commerce di Malaysia 2018. Retrieved September 10, 2018, from https://bomstart.my/statistik-pengguna-internetmedia-social-mobile-ecommerce-di-malaysia-2018/ 